\title{
VOLUME LOSS OF PULPWOOD IN MANITOBA CAUSED BY WOOD BORERS ${ }^{1}$
}

\author{
BY R. M. PRENTICE ${ }^{2}$ and A. E. CAMPBELL 2
}

\author{
R. M. PRENTICE
}

Served with the R.C.N.V.R. 1942-45; graduated University of Manitoba with the degree of B.S.A. in 1950, and became employed with the Division of Forest Biology at Winnipeg, Manitoba. Graduated from the University of Minnesota with the degree of M.S. in 1953.

A. E. CAMPBELL

Graduated from high school at Mafeking, Manitoba in 1934. Served with the R.C.N.V.R. 1940-45. Employed with the Manitoba Forest Service from 1945 to 1949, when he joined the staff of the Division of Forest Biology, Winnipeg, Manitoba.

\section{$A B S T R A C T$}

Measurements were made of the volume losses caused by wood borers in jack pine and black spruce pulpwood exposed to attack during the summer of 1956 in Manitoba. The average number of borer holes per square foot of log surface was 4.8 in jack pine and 6.5 in black spruce. Losses due to surface feeding and tunnelling were low and seldom exceeded 1.5 per cent of the volume of sample logs. These losses would not have offset the cost of chemical control. Cerambycid larvae accounted for most of the volume loss. Losses caused by buprestids were insignificant.

\section{INTRODUCTION}

With adverse conditions of hauling or stream-driving, woods operators in Manitoba are sometimes forced to leave large volumes of winter-cut pulpwood in yarding areas throughout the summer. During this period the wood is attacked by wood borers with a resulting loss in volume. Studies have been carried out to assess these losses in yarding areas of the Manitoba Pulp and Paper Company near Bear River in southeastern Manitoba.

Preliminary trials were carried out in 1953 by R. R. Lejeune and V. Hildahl (unpublished) to determine the practicability of chemical control of borers in pulpwood. A DDT water wettable spray (4 lb. of 50 per cent DDT to 5 gallons of water) was applied to piles of jack pine logs in mid-June and again in midJuly. This reduced the number of wood borer holes by about 75 per cent. However wood borers were not numerous in the study area in 1953, and the calculated volume loss on check logs never exceeded 0.1 per cent. These slight losses did not appear to warrant the cost of chemical control. Studies were continued in 1955 and 1956 to determine losses in years when borers were more abundant. A secondary objective was to refine the techniques used in measuring the volume of wood eaten by the larvae.

It was impractical to identify to species the borer larvae associated with each hole. However, subsequent rearings from sample logs indicated that the

\footnotetext{
${ }^{1}$ Contribution No. 500, Forest Biology Division, Science Service Department of Agriculture, Ottawa, Canada.
}

${ }^{2}$ Forest Biology Laboratory, Winnipeg, Manitoba. 
principal species were the sawyer beetle, Monochamus scutellatus (Say.) and two buprestids, Melanophila sp. and Chrysobothris sp.

\section{Methons}

Various techniques have been used for measuring the volume loss from borers feeding in pulpwood. McNeel (2) used molten Wood's Metal, which was poured into borer tunnels and allowed to harden. The casts of the metal were removed from the holes and their volumes measured. Flink (1) calculated the percentage of "area loss" on the face of sample discs using an "area comparison chart". He considered that the percentage of area loss was equal to volume loss. In preliminary studies at Winnipeg, estimates of volume loss were based on the average number and volume of feeding tunnels in sample logs.

These techniques have a common weakness. They fail to take into account the losses of wood that result from larvae feeding on the surface. Upon hatching, wood borer larvae feed for a period between the bark and the wood, causing a characteristic engraving on the wood surface (Fig. 1). In the present study both surface feeding and tunnelling losses were measured for estimates of volume losses.

Black spruce and jack pine trees were cut during the winter of 1955-56 and stacked in 1-cord piles at the Bear River yarding area. The wood was left undisturbed until the following November, when 11 jack pine and 8 black spruce sticks were taken from the piles. Both inside and outside sticks were represented in the sample. The sticks were peeled, the volumes calculated, and the entrance holes counted.

One hundred and thirty-two holes were measured in two steps to obtain an estimate of the average volume loss per hole. The first step was the measure-

TABLE 1

Volume loss Caused by Wood Borers in Jack Pine and Black Spruce Bear River, Manitoba, 1956

\begin{tabular}{|c|c|c|c|c|c|c|}
\hline \multirow[b]{2}{*}{$\begin{array}{c}\text { Tree } \\
\text { species }\end{array}$} & \multirow[b]{2}{*}{$\begin{array}{l}\text { Type of } \\
\text { borer }\end{array}$} & \multicolumn{2}{|c|}{ No. of holes } & \multicolumn{3}{|c|}{ Av. vol. losses per borer (cu. in.) } \\
\hline & & $\begin{array}{l}\overline{\text { Per sq. ft. }} \\
\text { of log } \\
\text { surface }\end{array}$ & Measured & $\begin{array}{l}\text { Surface } \\
\text { feeding }\end{array}$ & Tunnelling & $\begin{array}{l}\text { Percentage } \\
\text { vol. loss }\end{array}$ \\
\hline \multirow{3}{*}{$\begin{array}{l}\text { Jack } \\
\text { pine }\end{array}$} & Buprestidae & 1.5 & 14 & .03 & .03 & .03 \\
\hline & Cerambycidae & e 3.3 & 50 & .17 & .23 & .63 \\
\hline & TOTAL & 4.8 & 64 & .20 & .26 & .66 \\
\hline \multirow{3}{*}{$\begin{array}{l}\text { Black } \\
\text { spruce }\end{array}$} & Buprestidae & 1.8 & 18 & .02 & .03 & .02 \\
\hline & Cerambycidae & e 4.7 & 50 & .27 & .16 & 1.16 \\
\hline & TOTAL & 6.5 & 68 & .29 & .19 & 1.18 \\
\hline
\end{tabular}


ment of the volume of surface feeding. The areas were measured with a planimeter. Because of the varying depth of surface feeding, five points were picked at random and the depth of each measured with a steel rule graduated to $1 / 64$ inch (Fig. 2). Averages of depth and area were used to calculate volume loss from the surface feeding. Tunnels were exposed by a series of offset saw-cuts as shown in Figure 3. Tunnels were cleared of frass and their lengths measured with a wire as shown in Figure 4. In cross section, the tunnels are elliptical in shape. The major and minor axes were measured at three points along the tunnel and the volume calculated by the formula $\pi \mathrm{AB} \times \mathrm{L}$, where $\mathrm{A}$ is the

average major axis, and $\mathrm{B}$ is the average minor axis. None of the wood borer tunnels was completed and larvae were collected from most and classified into the broad groups of Cerambycidae and Buprestidae.

\section{Results ANd Conclusions}

The volume losses calculated for jack pine and black spruce are summarized in Table 1.

The volume loss caused by buprestids was relatively small and never exceeded 0.1 per cent in individual sample logs. The total volume loss in black spruce was about twice as high as in jack pine. Although both cerambycids and buprestids were more common in black spruce, the difference in the percentage of loss was partly due to the smaller size of the sample logs.

Surface feeding by wood bores accounted for about one half of the total loss. In black spruce the volume of surface feeding exceeded that of tunnelling, but in jack pine this relationship was reversed.

Borer numbers in 1956 were the highest that have been recorded in the Bear River area for over a 4-year period. However, the actual volume loss after exposure for one summer was not serious. Assuming a cost of $\$ 25.00$ per cord of unpeeled pulpwood delivered to the mill, the monetary loss in jack pine would be about $\$ 0.16$ per cord, and in black spruce about $\$ 0.26$ per cord. The cost of chemical spraying against borers in pulpwood was not calculated during the present study. Flink (1) estimated costs at $\$ 0.16$ per cord when treating large piles with heavy machine sprayers. Since complete control cannot be expected with chemical treatment, it would appear uneconomical to spray when wood borer numbers do not exceed those found in the Bear River area in 1956. This conclusion does not take into account wood decay which apparently accompanies borer attack. McNeel (2) states that this further reduces both the yield and quality of pulp.

It must be remembered that if wood attacked in 1956 were left in the yards or stock piled over a second summer, the losses would have been considerably greater than those calculated for one season only.

\section{REFERENCES}

1. FLINK, P. R. 1954. Report of the 1953 pulpwood spraying operation for control of wood borers. Mimeographed report. Forest Protection Laboratory, Iron Mountain, Michigan.

2. McNEEL, W., R. D. SHENEFELT and T. A. PASCOE. 1952. Insects in jack pine pulpwood. Pulp and Paper, pp. 86-89, August. 


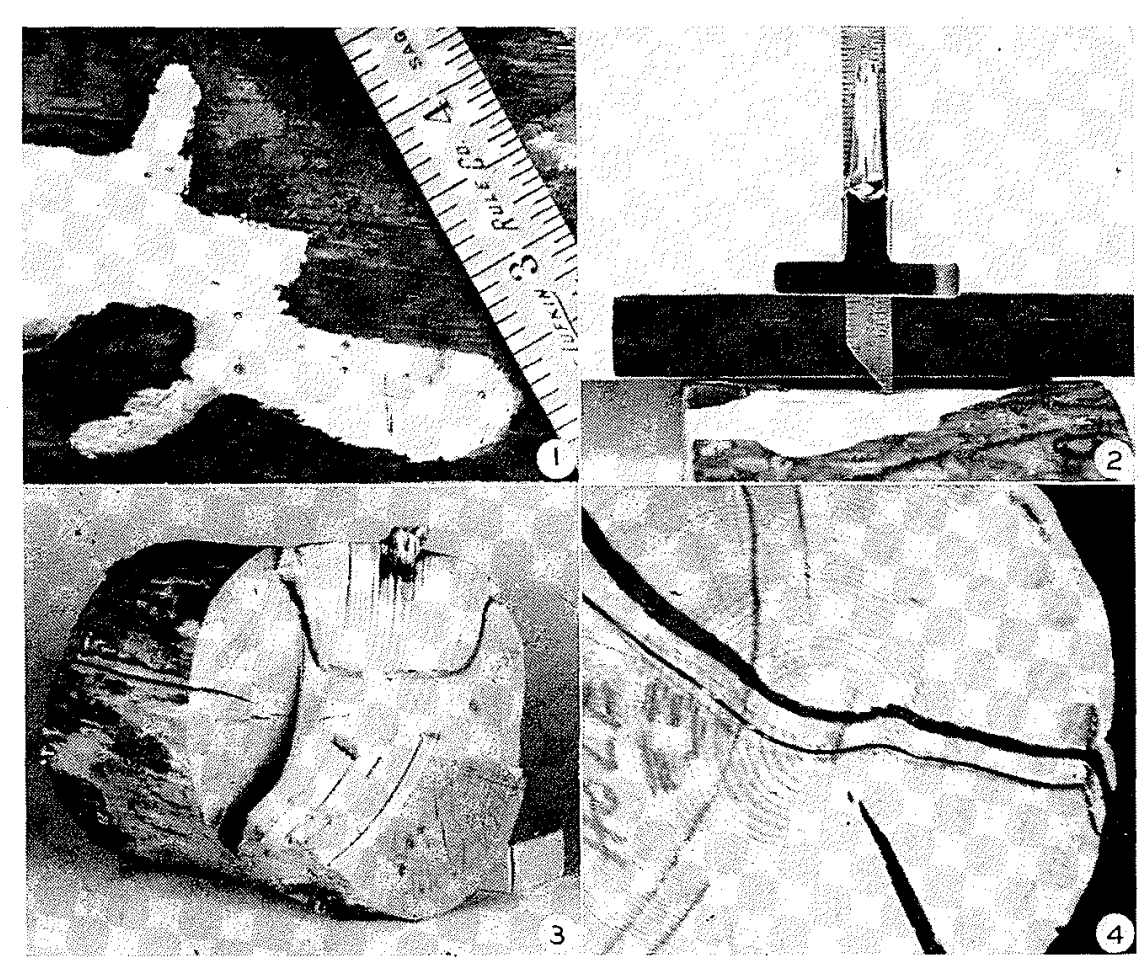

FIGURE 1

Surface fecding by a cerambycid larva on a jack pine stick.

FIGURE 2

Instrument used for measuring the depth of surface feeding.

FIGURE 3

Cerambycid tunnel exposed by a series of offset saw-cuts.

FIGURE 4

Tunnel cleared of frass and wire used for measuring the length of tunncl. 